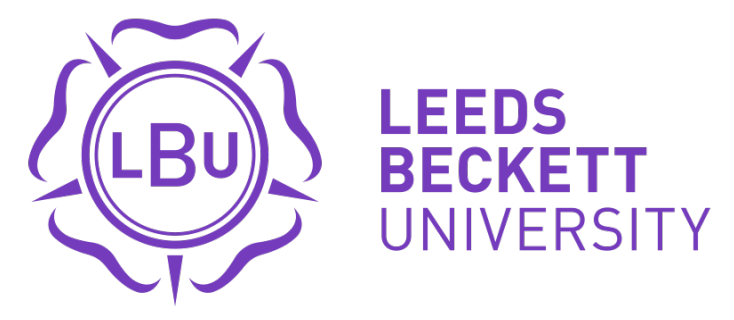

Citation:

Glyptou, K (2021) On the Verge Between Co-Creation and Co-Destruction: The Interesting Case of a Greek Traditional Cultural Event. Event Management. ISSN 1525-9951 DOI: https://doi.org/10.3727/152599521x16367300695753

Link to Leeds Beckett Repository record:

https://eprints.leedsbeckett.ac.uk/id/eprint/8447/

Document Version:

Article (Published Version)

Glyptou, Kyriaki (2021) On the Verge Between Co-Creation and Co-Destruction: The Interesting Case of a Greek Traditional Cultural Event. Event Management, https://doi.org/10.3727/152599521X16367300695753 The article(s) and/or figure(s) cannot be used for resale.

The aim of the Leeds Beckett Repository is to provide open access to our research, as required by funder policies and permitted by publishers and copyright law.

The Leeds Beckett repository holds a wide range of publications, each of which has been checked for copyright and the relevant embargo period has been applied by the Research Services team.

We operate on a standard take-down policy. If you are the author or publisher of an output and you would like it removed from the repository, please contact us and we will investigate on a case-by-case basis.

Each thesis in the repository has been cleared where necessary by the author for third party copyright. If you would like a thesis to be removed from the repository or believe there is an issue with copyright, please contact us on openaccess@leedsbeckett.ac.uk and we will investigate on a case-by-case basis. 
https://doi.org/10.3727/152599521X16367300695753

MS 20037 accepted for publication in Event Management

\title{
On the Verge Between Co-Creation and Co-Destruction: The Interesting Case of a
}

\section{Greek Traditional Cultural Event}

\author{
Dr. Kyriaki Glyptou
}

International Tourism Management, School of Events, Tourism and Hospitality Management Leeds Beckett University, Leeds, UK

\section{Author Note}

Dr. Kyriaki Glyptou: https://orcid.org/0000-0001-5881-7724

There is no conflict of interest to disclose.

Dr. Kyriaki Glyptou, Senior Lecturer in International Tourism Management, School of Events, Tourism and Hospitality Management, Leeds Beckett University, Leeds, UK;

Email:k.glyptou@1eedsbeckett.ac.uk 


\begin{abstract}
Traditional cultural events provide unique opportunities for resident-attendee destination experience and image co-creation, yet the cognitive, perceptual and behavioural disparities between these key actor groups remain rather sparse. Focusing on the process rather than the outcome of co-creation, this paper adopts a Service-Dominant Logic (SDL) to explore the underlying dynamics of social and economic actor encounters and their role in service value and image co-creation and destination resource management. More specifically, the study applies a mixed method approach to study the interface of social and psychological carrying capacity during the Easter Rocket War in Chios (Greece). Building on the particularities of this traditional event, the research identifies variables that trigger cognitive and perceptual conflicts of interests that may jeopardise an event's and a destination's image co-creation process, resulting in its co-destruction. Research findings contribute to the broader event image co-creation and destination branding body of literature, though the exploration of the underlying dynamics of multi-stakeholder and multi-attribute event dimensions (cultural, spiritual, historical, recreational). From a managerial perspective, research findings aim to inform destination planning and decision-making processes that dictate event viability, publicity and multi-stakeholder satisfaction.
\end{abstract}

Keywords: event co-creation; event co-destruction; destination carrying capacity; cultural event; Chios Easter Rocket War. 


\section{On the Verge Between Co-Creation and Co-Destruction: The Interesting Case of a Greek Traditional Cultural Event}

The recognition of traditional cultural events as strong pull factors for authentic experiences is well documented in the international literature. Consumers value uniqueness and authenticity and engage actively (consciously) or passively (unconsciously) in value and experience co-creation (Dimanche \& Andrades, 2014). The level of participation varies depending on the cognitive and perceptual values of the consumer yet, motivation and benefits rely both on the expected knowledge and emotions of affinity ascribed to the actual event (Campos et al., 2016; Chen \& Chen, 2010). Traditional cultural and religious events constitute curious cases for study since the role of institutions and official organisations is not always dominant nor leading. Even if, within their role, they facilitate the provision of the service ecosystem, it is often the local community which adopts both the roles of event producer and consumer (Jepson et al., 2014). Notwithstanding the key acting role of visitor attendees, authors acknowledge that multiple consumer participation is essential in the process of multi-dimensional event co-creation of value and experience (Prebensen et al., 2013). The aim of this paper hence lies into shedding light on the multiple facets and interfaces of destination and event carrying capacity as experienced by the various types of consumers, including local community itself.

Carrying capacity is traditionally considered amongst the key terms in defining the limits of growth in tourism destinations. According to UNWTO $(1981,4)$ carrying capacity reflects 'the maximum number of people that may visit a tourist destination at the same time, without causing destruction of the physical, economic, socio-cultural environment and an unacceptable decrease in the quality of visitors. In order to operationalise the concept in the context of events and destinations, the paper adopts Getz's (1983) differentiation of carrying capacity into six categories: physical, economic, ecological, political, social and 
psychological, with the last two deemed more relevant to the purposes of this research. Hereafter, social carrying capacity refers to the maximum use of an event resource that can take place without compromising the level of tolerance of the host community, whilst psychological carrying capacity reflects tourists' perceptual enjoyment limit beyond which, they perceive the event and tourism resource as overcrowded or degraded.

In delineating the dynamics and relationships between multiple traditional event consumers, the research aim of this paper is to explore those cognitive and perceptual boundaries that could jeopardise its social and psychological carrying capacity turning an event image co-creation into a co-destruction experience. To achieve that, the research builds on the Service-Dominant Logic approach which allows for the recognition of all social and economic actors involved in the service provision, value co-creation and resource management process (Della Corte et al., 2018). In the same time, it explores the caveat introduced by Plé and Cáceres (2010) recognising both co-creation and co-destruction as legitimate outcomes of exchange in events which are inherently characterised by both high risk and opportunity. The latest consideration only becomes more prominent in light of the conceptualisation of open event social and psychological carrying capacity in the context of ethical and socially responsible events that consider simultaneously both the benefits to the consumer but also the ethical and social implications associated with it (Smit \& Melissen, 2018).

Adopting Payne's et al. (2008) definition of co-creation as the process of integrating all stakeholders' perspectives and efforts towards the development of new products and services, this paper employs a mixed method approach to explore the contribution of multiple consumers (attendees and local community) in the image co-creation of a traditional cultural religious event in the island of Chios, Greece. Building on the particularities of the traditional Easter rocket war celebrations, this paper contributes to the broader event image co-creation 
and management body of literature, though the exploration of the underlying dynamics of multiple event attribute dimensions (cultural, spiritual, historical, recreational) associated with multiple stakeholder motivations. From a managerial perspective, research findings aim to inform event impact assessment as well as the planning and decision-making processes that dictate event viability, publicity and participant satisfaction.

\section{Theoretical Constructs and Research Hypotheses}

\section{Place Attachment}

Cultural events that build on local traditions have a very strong contextual meaning particularly in relation to place associated values (Quinn, 2003). According to environmental psychology, place attachment reflects all emotional responses people develop for a certain place based on the cognitive and affective information intelligence they associate with it (Davis, 2017; Lee et al., 2012; Ujang, 2017). According to Zhang et al. (2019), place attachments is conceptualised around place dependence and place identity. Place dependence relates mainly to the cognitive evaluation of the actual experience delivery to materialise within the specific spatial context, while place identity relates more to the affective image of all those intangible attributes associated with the specific place (Gu \& Ryan, 2008; Raymond et al., 2010). In the case of traditional cultural religious events, the differentiation between the two is rather subtle and not always clear. In fact, history, culture, gastronomy, customs, traditions and even language dialects are often strongly associated and triggered by specific landscape features. Within this context, place attachment endows events with unique features residing in their cultural and spatial authenticity (Suntikul \& Jachna, 2016), triggering attendees' image co-creation process. Certain authors (Getz, 2010; Hernández et al., 2007) go as far as to suggest that place attachment is amongst the primary mechanisms to foster visitor connection to an event, yet the co-creation experience extends beyond the affective appreciation of these features but rather to the active engagement and interaction with them 
(Davis, 2017). Building on research that suggests a positive relation between event satisfaction and place attachment, this research explores the following hypothesis:

H1: Place attachment has a significant effect on event image co-creation.

\section{Event Brand}

The brand of an event resides both on the unique features of the service delivery (output) but mainly on the event-associated experience (process) and values. In terms of their hedonistic service output, events can be associated with emotional reactions of thrill, pleasure and enjoyment from attending or, even better, engaging in an aesthetically appealing and exciting experience (Wakefield \& Blodgett, 1994). While event spectators engage in strong emotional reactions, they directly or indirectly (consciously or unconsciously) co-create an atmosphere of hedonic consumption that generates excitement and satisfies attendees' and participants' expectation for entertainment and stimulation (Uhrich \& Benkenstein, 2012). Notwithstanding the unique event exposure in terms of hedonic delivery (show), cultural events often entail a strong affiliation and long immersion into the cultural underlying background (Hernandez-Mogollon et al., 2018). Religious events in specific carry a strong spiritual attachment which has been well-proven to serve as pull factor for religious tourism pilgrimages over the years (Sharpley \& Jepson, 2011). Considering both aspects, cultural religious events can bare simultaneously recreational and edutaining value expectations that exceed beyond a first level hedonic or spiritual motivations and trigger engagement in the event experience co-creation process. In order to further explore how event brand perceptions and expectations affect the event image co-creation, the paper proposed the following research hypothesis:

H2: The perceived event brand has a significant effect on the event image cocreation. 


\section{User-Generated Content}

Social media and information sharing platforms are currently at the heart of any synchronous and asynchronous user-generated and distributed content. Other than sharing and communicating factual information on events and related activities, research suggests their key role in the formulation of a brand's affective image and value, hence customers' trust on the brand (Trinh \& Lam, 2016; Khadim et al., 2015). Amongst the information intelligence channels eWOM from actual event participants (unofficial sources), is considered as key catalyst in the formulation of image and brand perceptions, to convey the authentic and credible spectrum of the whole event experience (Brodie et al, 2013; Cheung \& Thadani, 2012). eWOM followers seem to be primarily interested in the communication of the emotional thrill generated during their participation and event experience (Llopis-Amorós et al., 2019). On the same way, participants themselves engage consciously or unconsciously in customer citizenship behaviour through the voluntary and discretionary generation of event-related content, hence contributing to the co-creation of event's image and publicity (Assiouras et al., 2019; Konovsky \& Pugh, 1994). The direct relationship between event satisfaction, loyalty and eWOM is well-documented in the literature (Kim et.al, 2010; Wong et.al, 2014). What remains to be further explored in the context of cultural traditional events, is the extent to which the generated experience-related content remains appealing to a broader audience other than to those sharing an affective attachment to the event's theme, and the arising implications for the event image co-destruction. Considering the broad reach of usergenerated content, this research proposes the following hypothesis:

H3. Event related user-generated content has a significant effect on the event image co-creation. 


\section{Interactions at Events}

For Getz (2010), interactions between providers and attendees are key catalysts for an event's success. Other than the place and brand attachment, the affective image of an event relies greatly on the quality and intensity of encounters and interactions during the overall experience (Rihova et al., 2018; Yang, 2016). Event interactions are well discussed in the context of value, experience and satisfaction co-creation (e.g., Campos et al., 2018; Mathis et al., 2016). Yet their implications on event experience co-destruction remain rather sparse, particularly in the context of cultural religious events. According to Davis (2017) encounters at events refer to either the customer-to-customer (attendee-to-attendee) interactions, or those between customers (attendees) and event providers. Within the context of cultural religious events organised by unofficial and informal local communities, attendee to event provider interactions need to be further differentiated between those local groups actively engaging in the delivery of the event versus those merely affeeted by it. The three types of interactions identified in this research are discussed in the context of their individual and aggregated contribution to an events' image

Tourists contribution in yalue and experience co-creation is well recognised (Vargo \& Lusch, 2008). In the case of events, attendees' interactions might be either direct interpersonal in the context of shared activities, or indirect in the broader event venue environment. Latané (1981) referred to a hedonistic arousal from the mere presence and activity of other event attendees, even those unacquainted. The more spectacular or intense the event output, the stronger the direct positive or negative emotional reactions from the attendees, but also the indirect emotional response to them (Gannon et al., 2019; Kim et al., 2019). Other than the quality of these interactions, Yang (2016) identifies their intensity to equally influence the overall experience. Even if on one hand, intense and frequent attendees' interactions may enhance the event co-creation experience through companionship or the co- 
stimulation of a festive vibe, excessive interactions might lead to an opposite co-destructive effect particularly for those strongly attached to the event theme. The impact of attendee-toattendee interactions has been well researched in the context of mega-events, yet research in relation to cultural religious and spiritual events it still sparse. This paper will aim to further clarify event image implications from attendee-to-attendee interactions for both religious and not tourists.

Local community is a key counter partner in traditional cultural events. Regardless of the event theme, host-guest encounters are the most common and frequent, hence greatly dictating the event experience. Local communities that maintain and perform traditional events in the context of their culture, history and way of life attribute an extra layer of uniqueness and authenticity in the event brand and experience. Positive experience from interactions induces a higher level of place and brand attachment and an affective event image that favours the whole experience (Guthrie \& Anderson, 2007). Similarly, feelings of discomfort, intrusion and frustration from local's end, might make attendees feel unwelcome and uncomfortable (Edvardsson et al.,2011). In cases of subtle boundaries between existing traditions and open events that built around them, personal attachment and engagement relates back to the primary motivation of attendance (Chen \& Rahman, 2018). If attendance and engagement from both hosts and guests is voluntary and builds around demonstrating the cultural identity of the event, both local communities as providers and attendees get to cocreate a strong event image and brand (Chi et al., 2018). If on the other hand, hosts' engagement and participation in the event is involuntary and only reliant on the mere spatial coexistence of locals and guests, attendees' presence can be even considered as intrusive (Järvi et al., 2018; Kashif \& Zarkada, 2015). The latest acquires an interesting gravitas in the context of religious events with underlying spiritual motivations where host-guest interaction dynamics might prove pivotal for the event co-destruction. 
All above identified encounters can be considered as interim interaction components during event's attendance and experience. Co-creation research addresses event participants as one group without differentiating between non-local attendees and the different roles of locals' engagement (Rihova et al., 2018; Zhang et al., 2019). The value of host-guests cocreation for locals' life satisfaction has been recognised at overall destination level (Lin et al., 2017). Still, the dynamics of their interim interrelations in the context of cultural traditional events and their implications for the events image require further exploration. In light of the above observations, this research proposes the following hypotheses:

H4. Attendee-to-attendee interactions during the event have a significant effect on the event image co-creation.

H5. Attendee to local community provider interactions during the event have a significant effect on the event image co-creation.

H6. Attendee to local community participant interactions during the event have a significant effect on the event image co-creation.

H7. Overall interactions during the event have a significant effect on the event image co-creation.

\section{Event Image Co-creation}

An event's image is defined along "the cumulative interpretation of meanings or associations attributed to events by consumers" (Gwinner, 1997, 147). In contrast to an event's brand identity which reflects its attributes and qualities from the provider's perspective (Kapferer, 2008), an event's image is ultimately formulated in the mind of events' actual and potential consumers. With events' marketing literature (Getz, 2008; Jafari, 2008; Oom do Valle et al., 2012) acknowledging the importance of external stakeholders as active contributors rather than passive recipients, an event's image co-creation reflects the participatory process where providers and consumers jointly formulate and evolve an event's 
cumulative meaning (Ind \& Coates, 2013). Whether cognitive, affective or conative, image strongly associated with the manifestation and interpretation of perceived value, hence, an event's image co-creation relates to the multi-stakeholder (attendees-participants) internalisation of the value experience and satisfaction generated from engagement and participation in the event. The more authentic and engaging the event experience, the higher the perception of exchange value creation (Chan et al, 2010).

Increased satisfaction of both event participants and attendees, whether local or nonlocal, translates into a shared appraisal of the co-created experience and a sustainable event image retainment within the context of local cultural consumption (Mathis et al., 2016). In adopting Payne's et al. (2008) approach that the value lies in the co-creation process, the harmonious interactions between key actors is catalytic for the event image and experience. Unfavourable dynamics that challenge the event-related psychological or social carrying capacity for any of the involved parties (attendees or participants) could put in jeopardy the shared exchange experience (Reisinger, 1994; Yolal, 2016) and trigger co-destruction processes that can be manifested through negative (e)WOM, a negative affective event image and primarily, a persistent underlying feeling of unrest and frustration at local level, which could potentially extend to the overall destination image (Mathis, 2016; Plé \& Cáceres, 2010; Smith, 2013).

\section{Proposed Event Image Co-creation model}

The theoretical underpinnings of the proposed model (Figure 1) reside in the Service Dominant Logic (SDL) to propose that consumers' and producers' engagement in traditional cultural event image co-creation, particularly if dictated by a varied system of perceived values, might evoke phenomena of co-destruction. SDL has been well used in event and festival studies to explore perceived values and the level and context of engagement in the events image co-creation process (Shaw et al., 2011; Vargo \& Lusch, 2008). SDL favours 
value co-creation along the dynamic social value exchange between event consumers and producers, while more recently it has been extended to consider all stakeholder roles in the broader service ecosystem (Della Corte et al., 2018). In the context of this paper, event image co-creation is assigned a more procedural than output dimension, hence service ecosystem obtains a more enabling environment dimension through the multiple underlying interactions (Edvardsson et al., 2011; Lin et al. 2017). In adopting Greer, Lusch, \& Vargo's (2016, p. 3) service ecosystem definition, SDL offers an integrative lense of the multiple exchange relationships formulated during an event experience, while considering the different value system and acting roles of key stakeholder groups and subgroups. Within this dynamic exchange context, both co-creation and co-destruction as legitimate outcomes of the event encounter (Plé \& Cáceres, 2010).

[Figure 1 around here]

\section{The Easter Rocket War of Chios}

Chios is an island in the North Aegean Region in Greece. With a population of traditionally and predominantly Orthodox Christians, Chios residents have built over the years culture and customs around their religious celebrations with Easter being the most sacred one. Dating back in the Ottoman era, two specific rival parishes run every year the rather curious and dangerous tradition of rocket war (Atlasobscura, nd). The homemade bottle rockets are prepared throughout the year by residents of the Vrondados area, often on the expense of their life, only to be slammed into the bell towers of the opposing parish church during the Resurrection midnight mass. The impressive spectacle of thousands of fire sticks shot simultaneously in the night-sky draws the attention of both domestic and international tourists, who these days are primarily pulled by the show rather than the religious pilgrimage. The event initially organised at small scale by local residents for the continuation of the tradition (approximately10,000 rocket thrown), overgrew its fame in the 
times of social media engaging in a vicious cycle of annually overbeating rocket records that reached approximately 150,000 in 2015 (cnn.gr, 2017). The less enthusiastic and frustrated local residents in the meantime, have found themselves trying to protect their property from fire and smoke, while some of them even move away for the duration of the celebrations. With the numbers of rockets produced in Vrondados now reduced as a response to the residential frustration, non-residents from other parts of the island seem to prepare their own rockets just to come in for the shooting during the event. The role of the official authorities at this stage is reduced on issues of safety, due to the difficulty of controlling numbers in open self-organised events.

The above reflects a reality of traditional cultural events that have exceeded their local reputation and turned into touristic attractions (Della Corte et al, 2018). It represents a case of multiple conflicting event consumer interests, with their roles and engagement remaining tangled and blurred. It seems that what started as an event co-creation experience based on the exchange of cultural and religious values is on the verge of co-destruction due to the compromise of its social and psychological carrying capacity. The economic and employment implications associated with the event attendance are beyond the scope of this research. In adopting a Service-Dominant Logic that recognises all consumers as key actors in event brand and value co-creation, this research will endeavour to explore the dynamics and boundaries of event customer roles and interactions, as well as their contribution towards the image co-creation of cultural traditional events.

\section{Research Method}

\section{Data Collection}

The research adopted a mixed method convergent design with simultaneous data collection, to explore the perceptions of the primary actor groups involved in the production and consumption of the event (Steinmetz-Wood et al., 2019). It more specifically followed 
the Good Reporting of A Mixed Methods Study (GRAMMS) that provides guidance on the design, purpose, sequence of methods, sampling, data collection, analysis and data integration (O'Cathain et al., 2008). The mixed method design allows for the triangulation of quantitative and qualitative research methods, hence offers the depth of analysis deemed most appropriate to capture the multiple stakeholder perceptions on the research topic. More specifically, the theoretical constructs were deducted from the literature review to develop the research hypotheses explored in the quantitative component of attendee surveys. The same constructs were used as key themes for the qualitative interview component with residents, while findings were inductively contextualized by means of a content analysis. The research was conducted in Chios during the pick of the 2019 orthodox Easter celebrations (26 April to 5 May).

\section{Quantitative Component}

A quantitative approach based on a closed structured questionnaire was preferred to capture perceptions and behaviour of the attendees' groups. Face to face questionnaire collection was preferred to the online version in order to capture tourists' behaviours and attitudes while still at destination. Participants were approached in public spaces in the capital of the island (Hora) up to one week after the delivery of the event and were selected merely on the basis of event attendance. Missing data were excluded listwise to allow the smoother analysis of the sample; a total of 391 (95\% response rate) completed questionnaires were used for the analysis.

For the quantitative data, the attendees sample size was calculated by means of Raosoft considering a population size of approximately 10,000 event attendees for the year 2019 (personal communication with local authorities), which suggests an appropriate sample size of over 370 participants. The sample size recommendation doesn't change much for larger populations (Raosoft, 2020), deeming the 391 sample as sufficient to extract reliable 
conclusions on a $<5 \%(4.86 \%)$ margin of error and a $95 \%$ confidence level. The proposed model fit was tested my means of the $\chi^{2}$, while the components validity and reliability was tested through loadings and Cronbach's Alpha. Structural Equation Modelling (SEM) was then employed to explore the linearity of relationships amongst the studied multivariate constructs.

In terms of measures, the questionnaire was structured around eight key constructs identified in the literature and a total of 47 statements, evaluated in a 1-5 Linkert response scale (1: Strongly Agree; 2: Agree; 3: Neither Agree nor Disagree; 4: Disagree; 5: Strongly Disagree and 6: Not relevant/applicable in my case). Three additional categorical variables were added to capture the age, gender and religious attachment of the participants. Statements were adapted from previous research on events and destination image studies. More specifically, the place attachment construct was based on Zhang et al. (2019), while event brand on the work of Hernandez-Mogollon et al. (2018). The statements on user-generated content was adapted from the Oliveira and Huertas (2019). The constructs of interactions were inspired from the work of Yang (2016) initially developed to measure tourist-to-tourist interactions. The use of the same constructs was extended to the other two actor groups to ensure the consistency and coherence of the analysis. The overall event interactions construct was based on a different set of statements of the same research. Finally, event image cocreation was based on the works of Lee \& Lee (2019) and Yi \& Gong (2013). The first has informed five statements on event togetherness, placeness and sacredness, while the latest those on advocacy.

\section{Qualitative Component}

Due to the lack of previous research on the topic, a qualitative approach was deemed most appropriate for an exploratory grounded information collection from local residents' residing in the area of the event (Hammarberg et.al, 2016, p. 499). In line with the attendee's 
survey, the semi-structured interview questions were developed around the eight research constructs identified through the literature review to allow for the triangulation of findings.

A total of 12 face-to-face interviews (seven males and five females, between 26-73 years old) were conducted. All interviewees were residing within meters from the two competing churches and all of them have been residing in the area for at least twenty-three years. For the purposes of this study, religious attachment has been defined beyond the concept of spirituality to only consider an individual's attending of religious services and engagement in religious rituals. The sample size deemed adequate to obtain data saturation in non-probabilistic sampling (Guest et al., 2006). Personal familiarisation of the researcher with residents of the area allowed a more in-depth exploration of the research themes. A few additional interviews were attempted through snowballing with other residents, but they remained rather superficial and didn't add depth nor content in the level of analysis, hence data saturation was considered achieved (Mason, 2002; Dworkin, 2012). All interviews were conducted in Greek, they lasted between 45 minutes to one and a half hour, were recorded and transcribed along the generic principles of thematic analysis. An inductive approach was applied for coding and theme development along a total of 172 statements (Kassarjian, 1977).

\section{Findings}

The socio-demographic descriptives of the two sample populations (attendees and residents) according to age, gender and religious attachment are summarized in Table 1 . The sample of attendees consisted primarily from ages 36-50 (54.7\%) with a medium level of religious attachment (60.6\%) and was rather gender-balanced with a slight majority of male participants $(54.5 \%)$. The sample of residents was primarily in the same age group, with a similar size majority of male interviewees, yet they declared to have a much stronger level of religious attachment. 


\section{Quantitative Analysis}

The descriptive statistics of the $391(\mathrm{~N})$ sample of Chios Easter Rocket War attendees are summarised in Table 2 along the mean, standard deviation, kurtosis and skewness of the sample. Place attachment to Chios seems to grow after attending the ERW (PA 2:1.87), as they seem to create many fond memories (PA 3: 1.97). For the attendees, the ERW brand is associated with a unique and authentic experience (EB 2:1.78), thus during their attendance they generate primarily affective content on their experience (UGC 4: 1.57) and cognitive on the actual event (UGC 1:1.84). In terms of their interactions, attendees identified encounters with other spectators as frequent (IA 4: 2.23) yet harmonious (IA 1:2.34). Similarly, they have identified interactions with local event providers and local community as primarily friendly (IP 2: 2.54) and harmonious (IC 1: 2.45) respectively. Overall encounters during the event made attendees experience an exciting (OI 4:2.15) and friendly (OI 1:2.34) event atmosphere. Finally, in terms of the ERW image co-creation, attendees strongly confirmed a sense of cultural traditions (EIC 2:1.24) and authenticity (EIC 3: 1.27) and seemed keen to recommend it to other people (EIC 6:1.57)

\section{Model Fit}

The goodness of fit of the proposed model was assessed based on the metrics deemed as most appropriate (Chen \& Chai, 2007; Kline, 2010; Pappas, 2016):

(a) for big sample sizes (in this case N: 391), the goodness of model's fit is assessed as $\chi^{2} / \mathrm{df}$. Good model fit is supported when $0 \leq \chi^{2} / \mathrm{df} \leq 2$.

(b) Comparative Fit Index (CFI), indicates better fits when is closer to 1.0

(c) Root Mean Square Error of Approximation (RMSEA), indicates close fits for values lower than .5 , and 
(d) Standardised Root-Mean-Square Residual (SRMR), indicates higher fits for values lower than .8 .

The tests returned a Confirmatory Factor Analysis (CFA) with $\chi^{2}=372.647$ and $\mathrm{df}=212(\mathrm{p}<.01)$ returning a $\chi^{2} / \mathrm{df}=1,758, \mathrm{CFI}=.947$; RMSEA $=.489$ and SRMR:.742 $(\mathrm{p}<.01)$ all indicating a good model fit.

\section{$<<<$ Table 3 around here $>>>$}

The CFA loading coefficients are summarised in Table 3 with absolute values suppressed to .4 (Norman \& Streiner, 2008). Cronbach's Alpha for the overall model reliability was .757 . For individual model constructs, all respective metric values were above the min accepted .7 value (Nunnally, 1978), ranging from a min. 723 for Interaction with Local Community Providers to max .851 for Place Attachment. Average Variance Extracted (AVE) for all individual constructs was over .5 indicating adequate convergent validity levels (Kim, 2014), while similarly, Composite Reliability (CR) of all constructs was above the recommended .7 acceptance level (Huang et al., 2013). Figure 2 summarises the confirmation of the hypotheses proposed by the event image co-creation model and delineates the relationships between the variables defining the profile of the participants.

\section{$<<<$ Figure 2 around here $>>>$}

\section{Qualitative Analysis}

A total of eighteen themes were identified from resident's perspectives under the eight research constructs: (a) Place Attachment: Community Togetherness, Reminiscence; (b) Event Brand: Size, Emotional Alienation, Religious Values, Disengagement, Loss of Local Character; (c) User-generated Content: Distancing, Fines; (d) Interaction with Event Attendees: Intensity, Quality; (e) Interaction with Local Community Providers: Conflicts, Marginalisation, Frustration; (f) Overall Interaction: Avoidance; Event Image Co-creation: Pride, Commodification, Experience. Table 4 summarizes the results of content analysis by 
research construct and provides sample statements for each of them. Interviewees are coded under gender $(\mathrm{M} / \mathrm{F})$, age and religious attachment $(\mathrm{S} / \mathrm{M} / \mathrm{L})$.

\section{$<<<$ Table 4 around here $>>>$}

The emergence of the above themes highlights primarily aspects of event's perceived cultural and emotional value and the importance of its continuation for the local culture and tradition. In terms of place attachment, the most prominent theme was Reminiscence $(58,3 \%)$ as the custom is a long family tradition for the residents of the area. The expansion of the brand of the event and the increase in its popularity and Size $(91,7 \%)$ were identified amongst the main reasons of affective Alienation (100\%) and perceived destress in social and psychological carrying capacity leading to emotional Disengagement $(58,3 \%)$ and eventually to the event image co-destruction for local residents. Amongst the interviewees, seven declared a strong religious attachment (attending services and engaging in rituals on a weekly basis), four a medium (attending services and engaging in rituals every couple of months) and one low (only attending main services and engaging in main rituals a few times per year). It, thus, shouldn't come as surprise the emergence of Religious Values $(66,7 \%)$ as another theme affected by the event's expansion. The plethora of attendees-generated content led locals to Distance (50\%) from openly generating and sharing content themselves, keeping it rather exclusively for a smaller elite of friends and relatives. In terms of interactions, locals primarily raised issues of Intensity (50\%), thus psychological carrying capacity of accommodating big numbers of attendees for a very short period of time. Yet, their main concerns were the implications for the social cohesion and social carrying capacity of the area, manifested through internal local society Frustration (83,3\%) and Marginalisation $(83,3 \%)$ of those expressing discontent with the situation, usually those directly affected by

it. Overall, locals seemed disheartened to further engage in the co-creation of the event's image despite the Pride $(41,7 \%)$ they take in their culture. Half of them consider it as a rather 
Commodified Experience (50\%) exaggerated as a tourism attraction that could be easily replicated somewhere else reducing in this way its place dependency and identity.

\section{Discussion}

In adopting the Service-Dominant Logic, this study aimed to address the concept of event image co-creation from the perception and experience viewpoint of key actors, namely event producers and consumers, and to explore the underlying implications of their encounters' dynamics. Building on the specificities of a traditional cultural religious event (Chen \& Rahman, 2018), the study applied a mixed method convergent approach to explore the impact of eight theoretical constructs in key actors' engagement in eyent image and to understand the underlying dynamics that could turn the co-creation into a co-destruction experience. The comparative analysis highlighted a number of issues in regard to the consumer-producer co-existence as interestingly, their interactions did not seem to cause the actual problem. In fact, based on the characteristics of the event, direct resident-attendee interactions could only occur during a period of maximum two or three hours. In this regard, the theoretical contribution of this research revolves in the domain of conflicting event perceptions and expectations where the successful image co-creation is not on the benefit of all key actors, henee entalling the seeds of its own co-destruction.

More specifically, participants from both event consumer and producer groups recognised the emotional attachment to the event and destination overall. They all recognised the uniqueness of the experience as delivered within the specific natural and cultural context (PA4), which contributes to the formulation of a strong affective event image (Lee et al., 2012). Interestingly, the common denominator for both groups was memories: the building of new ones for the attendees (PA3) and the Reminiscence of old ones for the locals (Memories). This finding confirms previous research (e.g. Raymond et al., 2010; Zhang et al., 2019) on the importance of place dependence and associated identity. For the specific 
locals, this seems to entail a more communal feeling of familiarity that allows interpersonal interactions with people in a smaller scale (Community Togetherness) that could be potentially attributed to the religious character of the event (Lee \& Lee, 2019). Event Brand was an interesting construct which revealed a number of contradicting preferences. What attendees considered as unique, authentic and exceptional experience that enjoys increasing good reputation at national level (EB2-EB3) were the exact reasons residents considered as a cause of commodification (Emotional Alienation) and cause for their emotional distancing (Disengagement). These findings support Chen \& Rahman's (2018) observations on memorable experience engagement in cultural contexts. In fact, residents have identified this increase in the number of bottle rockets produced (Size) and the involvement of non-residents (Loss of local character) to be the primary causes for their disengagement. In the context of servicespace (Wakefield, 1994) and co-creation/place attachment nexus (Suntikul \& Jachna, 2016), these could be experienced as a hurt in their local pride. Both groups seem to agree from their viewpoints that spirituality and religious attachment is not the main reason that tourists attend the event, which is in line with other case studies addressing religious events (e.g. Hernandez-Mogollon et al., 2018; Olsen, 2003).

User-generated content was another interesting construct; while attendees were expectedly (Uhrich \& Benkenstein, 2012) excited to share their hedonistic consumption experience (UGC4-UGC1) which is an essential point in their event image co-creation process, residents deliberately preferred to remain distant particularly from eWOM (Distancing). They claimed to prefer a more low-key communal event atmosphere, hence would rather share content only with interested friends and relatives than openly. As a result, the event image is primarily reduced to the final output (show) as experienced by the attendees, compromising the authentic process engagement and delivery element from the side of local residents and providers. This is in line with findings from Chi et al. (2018) in 
regard to the change of engagement process over time. Harder regulations on safety and event size from the local authority (Fines) seem to further constraint residents' interest in selfgenerating relevant content, leaving that role primarily to the attendees.

In terms of their interactions, attendees seem to enjoy an overall positive encounter experience with other spectators and locals. From their feedback they didn't seem to be able to differentiate between those directly involved in the delivery of the event against those merely residing in the area. Overall, they appreciated the friendly and pleasant event atmosphere (OI1-OI3) without expressing any concerns on the quality nor intensity of any of their interactions. This partially contradicts the experience described by Yang (2016), yet the differentiation can be attributed in the length of the event experience and the open space element. Interactions turned as a main concern from locals' perceptive. Even if they reported minimum direct interactions with attendees, their perceived psychological carrying capacity felt undermined and intruded. Some interviewees even reported moving away from the area for the time around the event (Avoidance). More importantly though, the underlying conflicts of interests between local residents as event providers and as involuntary participants evokes feelings of social unrest and distress due to the compromise of the social carrying capacity (Frustration and Marginalisation). All above findings are summarised in both resident groups' perceptions suggesting conflicting perceptions of event image, value and experience and planting the seeds for co-destruction.

\section{Conclusions}

The study explores the interface and dynamics between event image co-creation and co-destruction. Building on the traditional religious event of Easter Rocket War in Chios (North Aegean Region, Greece), the study employed a Service-Dominant Logical (SDL) approach to explore the engagement and contribution of consumers (attendees) and producers (groups of local residents) in the event image co-creation. Findings suggest that conflicts of 
perceptions, values and expectations influence the affective image of the event per cohort, that could potentially lead to a co-destructive outcome. It then lies to elements of establishing boundaries of carrying capacity which can evolve in itself as co-creative process.

Findings reflect the particularities of the Easter Rocket War of Chios and should be considered along the characteristics of the event (intensity, duration, theme) as well as the overall tourism profile of the island. A discussion on the role of official authorities is beyond the scope of this paper, yet future research could extend to consider their involvement as an additional stakeholder. Cultural traditional open events of this type remain organised and delivered voluntarily by residents, hence require bottom-up participatory and inclusive management approaches. Further research is required to explore the implications from the expansion of traditional custom-based open events, particularly in relation to the carrying capacity of the directly affected resident population. Methodologically, the research could further explore the perceptions of local residents delivering the event in order to enhance the understanding of their underlying motivations and pivotal role in the image co-creation process.

Current findings suggest that perceptual boundaries of social and psychological event carrying capacity depend on the perceived and expected event values. The measurement and operationalisation of the various facets of open cultural event carrying capacity was beyond the scope of this paper. Such research would require a different approach and structure of research construct development and measurement. Instead, the current research offers a first rapport on the conflicting attributes putting in jeopardy the event's overall image from each consumer's perspective and value system. Interestingly, the challenge is primarily perceptual as the actual interaction between hosts and attendees is rather limited in time. Its intensity lies primarily in the perception of the "intruding" element of attendees' engagement, in the expense of local cultural, spiritual and traditional values. In consideration to these findings on 
the limited interactions between event consumers and producers, research could explore potential direct and indirect encounter opportunities that could extend the duration of the experience and enhance its participatory co-creating value.

In terms of managerial implications, the study adds to the increasing body of literature on the divergence between co-creation and co-destruction (Plé \& Cáceres, 2010). Even if specialised in the context of cultural traditional open space and self-organised events, the research still raises issues of conflicts of perceptions, values and experiences, which could turn pivotal in the co-creation of an event's image and brand (Payne et al., 2009). It is not the cognitive image of an event which is at stake but rather the affective one due its multiple attributed facets. The Service-Dominant Logic recognises the role of local actors as selforganisers in the co-creation process (Della Corte, 2018), yet further complexity resides within their different roles and interests. In recognising the challenge of reaching a consensus, a starting point seems to revolve around the identification of event-related social and psychological carrying capacity that ensures the quality of experience for all involved actors, while ensuring authenticity and safeguarding its continuity. 


\section{References}

Assiouras, I., Skourtis, G., Giannopoulos, A., Buhalis, D., \& Koniordos, M. (2019). Value co-creation and customer citizenship behaviour. Annals of Tourism Research, 78, 1027-1042. https://doi.org/10.1016/j.annals.2019.102742

Atlasobscura (nd) Chios Rocket War. https://www.atlasobscura.com/places/chios-rocket-war$\underline{\text { rouketopolemos }}$

Brodie, R.J., Ilic, A., Juric, B., \& Hollebeek, L. (2013). Consumer engagement in a virtual brand community: an exploratory analysis. Journal of Business Research, 66(1), 105114. https://doi.org/10.1016/j.jbusres.2011.07.029

Campos, A. C., Mendes, J., Oom do Valle, P., \& Scott, N. (2016), Co-creation experiences: attention and memorability. Journal of Travel \& Tourism Marketing, 33, 1309-1336. https://doi.org/10.1080/10548408.2015.1118424

Campos, A. C., Mendes, J., Valle, P. O. D., \& Scott, N. (2018). Co-creation of tourist experiences: A literature review Current Issues in Tourism, 21(4), 369-400. https://doi.org/10.1080/13683500.2015.1081158

Chan, K. W., Yim, C. K., \& Lam, S. S. (2010). Is customer participation in value creation a double-edged sword? Evidence from professional financial services across cultures. Journal of Marketing, 74(3), 48-64. https://doi.org/10.1509/jmkg.74.3.048

Chen, C.-F., \& Chen, F.-S. (2010). Experience quality, perceived value, satisfaction and behavioural intentions for heritage tourists. Journal of Tourism Management, 31(1), 29-35. https://doi.org/10.1016/j.tourman.2009.02.008

Cheung, C. M., \& Thadani, D. R. (2012). The impact of electronic word-of-mouth communication: A literature analysis and integrative model. Decision Support Systems, 54 (1), 461-470.https://doi.org/10.1016/j.dss.2012.06.008 
Chen, C.-F., \& Tsai, D. (2007). How destination image and evaluative factors affect behavioral intentions? Tourism Management, 28(4), 1115-1122. https://doi.org/10.1016/j.tourman.2006.07.007

Chen, H., \& Rahman, I. (2018). Cultural tourism: An analysis of engagement, cultural contact, memorable tourism experience and destination loyalty. Tourism Management Perspectives, 26, 153-163. https://doi.org/10.1016/j.tmp.2017.10.006

Chi, C. G.-Q., Ouyang, Z., \& Xu, X. (2018). Changing perceptions and reasoning process: Comparison of residents' pre-and post-event attitudes. Annals Tourism Research, 70, 39-53. https://doi.org/10.1016/j.annals.2018.02.010

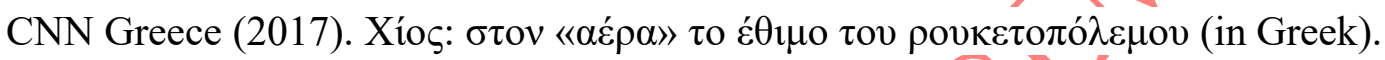
https://www.atlasobscura.com/places/chios-rocket-war-rouketopolemos

Davis, A. (2017). Experiential places or places of experience? Place identity and place attachment as mechanisms for creating festivval environment. Tourism Management, 55, 49-61. https://doi.org/10.1016/).tourman.2016.01.006

Della Corte, V., Sepe, F., Storlazzi, A., \& Savastano, I. (2018). Citizen cocreation in tourist and cultural events. Event Management, 22, 643-654. https://doi,org/10.3727/152599518X15300559277001

Dimanche, F., \& Andrades, L. (2014). Co-creation of experience value: A tourist behaviour approach. In N. K Prebensen, J. S. Chen, \& M. Uysal (Eds.), Creating experience value in tourism (pp. 95-112). https://doi.org/10.1079/9781780643489.0095

Dworkin, S. L. (2012). Sample size policy for qualitative studies using in-depth interviews. Archives of Sexual Behavior, 41, 1319-1320. https://doi.org/10.1007/s10508-012$\underline{0016-6}$ 
Edvardsson, B., Tronvoll, B., \& Gruber, T. (2011). Expanding understanding of service exchange and value co-creation: a social construction approach. Journal of the Academy of Marketing Science, 39, 327-339. https://doi.org/10.1007/s11747-010$\underline{0200-\mathrm{y}}$

Gannon, M., Taheri, B., \& Olya, H. (2019). Festival quality, self-connection, and bragging. Annals of Tourism Research, 76, 239-252. https://doi.org/10.1016/j.annals.2019.04.014

Getz, D. (2010). The nature and scope of festival studies. Internationah Journal of Event Management Research, 5(1), 1-47. http://ijemr.org/wpcontent/uploads/2014/10/Getz.pdf

Getz, D. (2008). Event tourism: Definition, evolution, and research. Tourism Management, 29(3), 403-428.https://doi.org/10.1016/i.tourman.2007.07.017

Getz, D. (1983). Capacity to absorb tourism: Coneepts and implications for strategic planning. Annals of Tourism Research, 10(2), 239-263. https://doi.org/10.1016/0160$\underline{7383(83) 90028-2}$

Greer, C. R., Lusch, R. F., \& Vargo, S. L. (2016). A service perspective: Key managerial insights from service-dominant (S-D) logic. Organizational Dynamics, 45(1), 28-38. https://doi.org/10.1016/j.orgdyn.2015.12.004

Gu, H., \& Ryan, C. (2008). Place attachment, identity and community impacts of tourismthe case of a Beijing hutong. Tourism Management, 29(4), 637-647. https://doi.org/10.1016/j.tourman.2007.06.006

Guest, G., Bunce, A., \& Johnson, L. (2006). How many interviews are enough? An experiment with data saturation and variability. Field Methods, 18 (1), 59-82. https://doi.org/10.1177/1525822X05279903 
Guthrie, C., \& Anderson, A. (2007). Tourists on tourists: The impact of other people on destination experience. In J. Tribe \& D. Airey (Eds.), Tourism research: New directions, challenges and applications, Chapter 10 (143-155). New York, NY: Routledge.

Gwinner, K. (1997). A model of image creation and image transfer in event sponsorship. International Marketing Review, 14(3), 145-158. https://doi.org/10.1108/02651339710170221

Hammarberg, K., Kirkman, M., \& de Lacey, S. (2016). Qualitative research methods: When to use them and how to judge them. Human Reproduction, 31(3), 498-501. https://doi.org/10.1093/humrep/dev334

Hernández, B., Hidalgo, M. C., Salazar-Laplace, M.E., \& Hess, S. (2007). Place attachment and place identity in natives and non-natives. Journal of Environmental Psychology, 27(4), 310-319. https://doi.org/10.1016/1.jenvp.2007.06.003

Hernández-Mogollón, J. M., Duarte, P. A., \& Folgado-Fernández, J. A. (2018). The contribution of cultural events to the formation of the cognitive and affective images of a tourist destination. Journal of Destination Marketing \& Management, 8, 170178. https://doi.org/10.1016/j.jdmm.2017.03.004

Jafari, J. (2008). Transforming culture into events: Faux pas and judicious deliberations. In Proceedings of the International Tourism Conference Cultural and Event Tourism: Issues and Debates (1-9). Detay Yayincilik.

Järvi, H., Kähkönen, A.-K., \& Torvinen, H. (2018). When value co-creation fails: Reasons that lead to value co-destruction. Scandinavian Journal of Management, 34(1), 63-77. https://doi.org/10.1016/j.scaman.2018.01.002

Jepson, A., Clarke, A., \& Ragsdell, G. (2014). Integrating "self-efficacy" theory to the Motivation-Opportunity-Ability (MOA) model to reveal factors that influence 
inclusive engagement within local community festivals. International Journal of Event and Festival Management, 5(3), 219-234. https://doi.org/10.1108/IJEFM-11$\underline{2013-0027}$

Kashif, M., \& Zarkada, A. (2015). Value co-destruction between customers and frontline employees: A social system perspective. International Journal of Bank Marketing, 33(6), 672-691. https://doi.org/10.1108/IJBM-09-2014-0121

Kassarjian, H. H. (1977). Content analysis in consumer research. Journal of Consumer Research, 4(1), 8-18. https://doi.org/10.1086/208674

Kim, J.-H. (2014). The antecedents of memorable tourism experiences: The development of a scale to measure the destination attributes associated with memorable experiences. Tourism Management, 44, 34-45. https://doi,org/10.1016/j.tourman.2014.02.007

Kim, Y. H., Kim, M., Ruetzler, T., \& Taylor, J.(2010),An examination of festival attendees' behaviour using SEM. International Journal of Event and Festival Management, 1(1), 86-95. https://doi.org/10.1108/17852951011029324

Kim, S., Stylidis, D., \& Oh, M. (2019). Is perception of destination image stable or does it fluctuate? A measurement of three points in time. International Journal of Tourism Research, 21(4), 447-461. https://doi.org/10.1002/jtr.2273

Kline, R.B. (2010). Principles and practice for structural equation modelling ( $3^{\text {rd }}$ Ed.). Guildford Publications.

Khadim, R. A., Younis, M. S., Mahmood, A., \& Khalid, R. (2015). Firm-created social media communication and consumer brand perceptions. International Journal of Marketing and Technology, 5(3), 91-105.

Konovsky, M. A., \& Pugh, S. D. (1994). Citizenship behaviour and social exchange. Academy of Management Journal, 37(3), 656-669. https://doi.org/10.5465/256704 
Lee, K-Y, \& Lee, H. (2019). Traditional costume experience at a cultural heritage festival. Tourism Management Perspectives, 32, 100555.

https://doi.org/10.1016/j.tmp.2019.100555

Lee, J. S., Lee, C. K., \& Choi, Y. (2011). Examining the role of emotional and functional values in festival evaluation. Journal of Travel Research, 50(6), 685-696. https://doi.org/10.1177/0047287510385465

Lee, J., Kyle, G., \& Scott, D. (2012). The mediating effect of place attachment on the relationship between festival satisfaction and loyalty to the festival hosting destination. Journal of Travel Research, 51(6), 754-767. https://doi.org/10.1177/0047287512437859

Lin, Z., Chen, Y., \& Filieri, R. (2017). Resident-tourist value co-creation: The role of residents' perceived tourism impacts and life satisfaction. Tourism Management, 61, 436-442. https://doi.org/10.1016/j.tourman.2017.02.013

Liu, C.-R., Wang, Y.-C., Huang W.-S., \& Tang, W.-C.. (2019). Festival gamification: Conceptualisation and scale development. Tourism Management, 74, 370-381. https://doi.org/10.1016/j.tourman.2019.04.005

Llopis-Amorós, M.-P., Gil-Saura, I., Ruiz-Molina, M. E., \& Fuentes-Blasco, M. (2019). Social media communications and festival brand equity: Millennials vs Centennials. Journal of Hospitality and Tourism Management, 40, 134-144. https://doi.org/10.1016/j.jhtm.2019.08.002

Luo, J., Wong, I. A., King, B., Liu, M. T., \& Huang, G. (2018). Co-creation and codestruction of service quality through customer-to-customer interactions: Why prior experience matters. International Journal of Contemporary Hospitality Management, 31(3), 1309-1329. https://doi.org/10.1108/IJCHM-12-2017-0792

Mason, J. (2002). Qualitative Researching (2 ${ }^{\text {nd }}$ Ed.). Sage Publications. 
Matheson, C. M., Rimmer, R., \& Tinsley, R. (2014). Spiritual attitudes and visitor motivations at the Beltane Fire Festival, Edinburgh. Tourism Management, 44, 16-33. http://doi.org/10.1016/j.tourman.2014.01.023

Mathis, E. F., Kim, H. L., Uysal, M., Sirgy, J. M., \& Prebensen, N. K. (2016). The effect of co-creation experience on outcome variable. Annals Tourism Research, 57, 62-75. https://doi.org/10.1016/j.annals.2015.11.023

Norman, G., \& Streiner, D. (2008). Biostatistics: The bare essentials ( $\left.3^{\text {rd }} \mathrm{Ed}\right)$. Decker: Hamilton.

Nunnally, J. C., (1978). Psychometric theory. McGraw-Hill.

O'cathain, A., Murphy, E., \& Nicholl, J. (2008). The quality of mixed methods studies in health services research. Journal of Health Services Research and Policy, 13(2), 9298. https://doi.org/10.1258/jhsrp.2007.007074

Oliveira, A., \& Huertas, A. (2019). How do destination use Twitter to recover their images after a terrorist attack. Journal of Destination Marketing and Management, 12, 46-54. https://doi.org/10.1016/1.jdmm.2019.03.002

Oom do Valle, P., Mendes, J., \& Guerreiro, M. (2012). Residents' participation in events, events image, and destination image: A correspondence analysis. Journal of Travel \& Tourism Marketing, 29(7), 647-664. https://doi.org/10.1080/10548408.2012.720151

Pappas, N. (2016). Marketing strategies, perceived risks, and consumer trust in online buying behavior. Journal of Retailing and Consumer Services, 29, 92-103. https://doi.org/10.1016/j.jretconser.2015.11.007

Payne, A. F., Storbacka, K., \& Frow, P. (2008). Managing the co-creation of value. Journal of the Academy of Marketing Science, 36, 83-96. https://doi.org/10.1007/s11747-007$\underline{0070-0}$ 
Payne, A., Storbacka, K., Frow, P., \& Knox, S. (2009). Co-creating brands: Diagnosing and designing the relationship experience. Journal of Business Research, 62(3), 379-389. https://doi.org/10.1016/j.jbusres.2008.05.013

Plé, L., \& Cáceres, R. C. (2010). Not always co-creation: Introducing interactional codestruction of value in service-dominant logic. Journal of Services Marketing, 24(6), 430-437. https://doi.org/10.1108/08876041011072546

Prebensen, N. K., Vittersø, J., \& Dahl, T. I. (2013). Value co-creation significance of tourist resources. Annals of Tourism Research, 42, 240-261. https://doi.org/10.1016/j.annals.2013.01.012

Quinn, B. (2003). Symbols, practices and myth-making: Cultural perspectives on the Wexford Festival Opera. Tourism Geographies, 5(3), 329-349. https://doi.org/10.1080/14616680309710

Raymond, C. M., Brown, G., \& Weber, D. (2010). The measurement of place attachment: personal, community, and environmental connections. Journal Environmental Psychology, 30(4), 422-434. https://doi.org/10.1016/j.jenvp.2010.08.002

Reisinger, Y. (1994). Tourist-Host contact as a part of cultural tourism. World Leisure \& Recreation, 36(2), 24-28.https://doi.org/10.1080/10261133.1994.9673910

Rihova, I., Buhalis, D., Gouthro, M. B., \& Moital, M. (2018). Customer-to-customer cocreation practices in tourism: Lessons from customer-dominant logic. Tourism Management, 67, 362-375. https://doi.org/10.1016/j.tourman.2018.02.010

Sharpley, R., \& Jepson, D. (2011). Rural tourism: A spiritual experience? Annals of Tourism Research, 38(1), 52-71. https://doi.org/10.1016/j.annals.2010.05.002

Shaw, G., Bailey, A., \& Williams, A. (2011). Aspects of service-dominant logic and its implications for tourism management: Examples from the hotel industry. Tourism Management, 32(2), 207-214. https://doi.org/10.1016/j.tourman.2010.05.020 
Smit, B., \& Melissen, F. (2018). Sustainable customer experience design. Co-creating experiences in Events, Tourism and Hospitality, ( ${ }^{\text {st }}$ Ed.). Routledge.

Smith, A. M. (2013). The value co-destruction process: A customer resource perspective. European Journal of Marketing, 47(11/12), 1889-1909. https://doi.org/10.1108/EJM$\underline{08-2011-0420}$

Steinmetz-Wood, M., Pluye, P., \& Ross, N. A. (2019). The planning and reporting of mixed methods studies on the built environment and health. Preventive Medicine, 105752. https://doi.org/10.1016/j.ypmed.2019.105752

Suntikul, W., \& Jachna, T. (2016). The co-creation/place attachment nexus. Tourism Management, 52, 276-286. https://doi.org/10.1016/7.tourman.2015.06.026

Trinh, G., \& Lam, D. (2016). Understanding the attendance at cultural venues and events with stochastic preference models. Journal of Business Research, 69(9), 3538-3544. https://doi.org/10.1016/j.jbusres.2016.01.033

Uhrich, S., \& Benkenstein, M. (2012). Physical and social atmospheric effects in hedonic service consumption: Customers' roles at sporting events. Service Industry Journal, 32(11), 1741-1757. https://doi.org/10.1080/02642069.2011.556190

Ujang, N. (2017). Place attachment and continuity of urban place identity. Asian Journal of Environmental Studies, 2(2), 117-132. https://doi.org/10.1016/j.sbspro.2012.07.014 UNWTO (1981). Saturation of Tourist Destinations. Report of the Secretary General, World Tourism Organisation, Madrid.

Vargo, S. L., \& Lusch, R. F. (2008). Service-dominant logic: Continuing the evolution. Journal of the Academy of Marketing Science, 36(1), 1-10. https://doi.org/10.1007/s11747-007-0069-6 
Wakefield, K. L., \& Blodgett, J. G. (1994). The importance of servicescapes in leisure service settings. Journal of Service Marketing, 8, 66-76.

https://doi.org/10.1108/08876049410065624

Wong, J., Wu, H.-C., \& Cheng, C.-C. (2014). An empirical analysis of synthesizing the effects of festival quality, emotion, festival image and festival satisfaction on festival loyalty: A case study of Macau food festival. International Journal of Tourism Research, 17(6), 521-536. https://doi.org/10.1002/jtr.2011

Yang, F.X. (2016). Tourist co-created destination image. Journal of Travel and Tourism Marketing, 33(4), 425-439. https://doi.org/10.1080/10548408.2015.1064063

Yi, Y., \& Gong, T. (2013). Customer value co-creation behavior: scale development and validation. Journal of Business Research, 66(9), 1279-1284. https://doi.org/10.1016/j.jbusres.2012.02.026

Yolal, M., Gursoy, D., Uysal, M., Kim, H.-L., \& Karacaoğlu, S. (2016). Impacts of festivals and events on residents' well-being. Annals of Tourism Research, 61, 1-18. https://doi.org/10.1016/ A.annals.2016.07.008

Zhang, C. X., Nang Fong, L. C., \& Li, S. (2019). Co-creation experience and place attachment. Festival evaluation. International Journal of Hospitality Management, 81, 193-204. https://doi.org/10.1016/j.ijhm.2019.04.013 


\section{Table 1}

Socio-Demographic Characteristics of the Studied Sample.

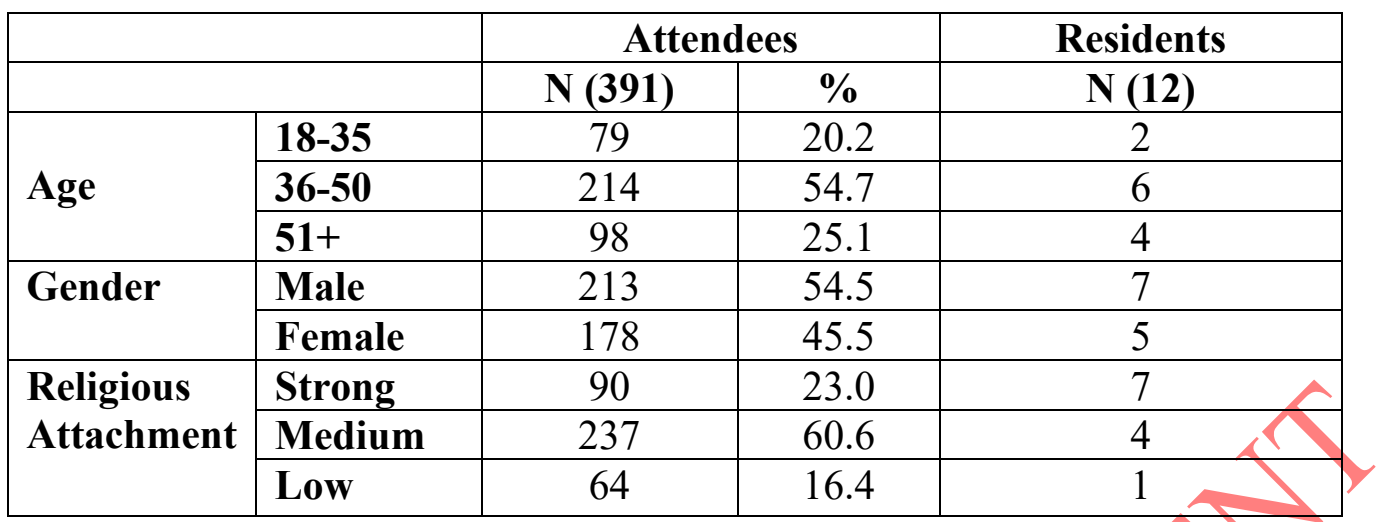

No respondent identified themselves under the option of Gender: Prefer not to answer, hence is excluded from the Table of Descriptives. 
Table 2

Descriptive Statistics

\begin{tabular}{|c|c|c|c|c|c|}
\hline \multirow{2}{*}{\multicolumn{2}{|c|}{$\begin{array}{l}\text { Statement } \\
\text { Place Attachment (Zhang et al. 2019) }\end{array}$}} & \multirow[t]{2}{*}{ Mean } & \multirow[t]{2}{*}{ Std. Dev. } & \multirow[t]{2}{*}{ Kurtosis } & \multirow[t]{2}{*}{ Skewness } \\
\hline & & & & & \\
\hline PA1 & $\begin{array}{l}\text { Attending the Chios ERW is } \\
\text { very special to me }\end{array}$ & 2.20 & .962 & .462 & -.934 \\
\hline PA2 & $\begin{array}{l}\text { I am very attached to Chios } \\
\text { after attending the ERW }\end{array}$ & 1.87 & .882 & .789 & -.781 \\
\hline PA3 & $\begin{array}{l}\text { I have a lot of fond memories } \\
\text { of Chios after attending the } \\
\text { ERW }\end{array}$ & 1.97 & .862 & .562 & -.823 \\
\hline PA4 & $\begin{array}{l}\text { For Easter celebrations, no } \\
\text { other place can compare to } \\
\text { Chios }\end{array}$ & 2.35 & .945 & & -.967 \\
\hline PA5 & $\begin{array}{l}\text { I wouldn't substitute any } \\
\text { other place for having the } \\
\text { Easter experience I have in } \\
\text { Chios }\end{array}$ & 2.25 & & & -.894 \\
\hline \multicolumn{6}{|c|}{ Event Brand (Hernandez-Mogollon et al., 2018) } \\
\hline EB1 & $\begin{array}{l}\text { I feel that the Chios ERW is a } \\
\text { well-known event at national } \\
\text { level }\end{array}$ & & .845 & -.362 & -.634 \\
\hline EB2 & $\begin{array}{l}\text { I feel that the Chios ERW is a } \\
\text { unique event that offers an } \\
\text { authentic experience }\end{array}$ & 1.78 & .822 & .257 & .567 \\
\hline EB3 & $\begin{array}{l}\text { When I think about Easter } \\
\text { celebration events, the Chios } \\
\text { ERW comes immediately in } \\
\text { mind }\end{array}$ & 2.34 & .967 & .275 & .356 \\
\hline EB4 & $\begin{array}{l}\text { I get a personal sense of pride } \\
\text { through participating in the } \\
\text { Chios ERW }\end{array}$ & 2.24 & .912 & -.234 & -.657 \\
\hline EB5 & $\begin{array}{l}\text { I get a personal sense of } \\
\text { excitement through } \\
\text { participating in Chios ERW }\end{array}$ & 2.02 & .832 & .264 & .562 \\
\hline EB6 & $\begin{array}{l}\text { I get a personal sense of } \\
\text { spiritual attachment through } \\
\text { participating in the Chios } \\
\text { ERW }\end{array}$ & 2.78 & .852 & .145 & -.642 \\
\hline \multicolumn{6}{|c|}{ User-generated content (Oliveira and Huertas, 2019) } \\
\hline UGC1 & $\begin{array}{l}\text { Whilst attending the Chios } \\
\text { ERW, I shared content on the } \\
\text { actual event }\end{array}$ & 1.84 & .856 & .143 & .612 \\
\hline UGC2 & $\begin{array}{l}\text { Whilst attending the Chios } \\
\text { ERW, I shared content on the } \\
\text { event management and role of } \\
\text { stakeholders }\end{array}$ & 3.12 & .943 & .435 & .345 \\
\hline
\end{tabular}




\begin{tabular}{|c|c|c|c|c|c|}
\hline UGC3 & $\begin{array}{l}\text { Whilst attending the Chios } \\
\text { ERW, I shared content on the } \\
\text { safety of attendees (security } \\
\text { measures and advice on } \\
\text { locations) }\end{array}$ & 3.67 & .822 & -.462 & -.435 \\
\hline UGC4 & $\begin{array}{l}\text { Whilst attending the Chios } \\
\text { ERW, I shared content on the } \\
\text { event experience }\end{array}$ & 1.57 & .891 & .512 & -.456 \\
\hline UGC5 & $\begin{array}{l}\text { Whilst attending the Chios } \\
\text { ERW, I shared content on the } \\
\text { event promotion }\end{array}$ & 2.89 & .932 & .231 & .654 \\
\hline \multicolumn{6}{|c|}{ Interaction with Event Attendees (Yang, 2016) } \\
\hline IA1 & $\begin{array}{l}\text { My interaction with other } \\
\text { event attendees (spectators) } \\
\text { was harmonious }\end{array}$ & 2.34 & .856 & & -.682 \\
\hline IA2 & $\begin{array}{l}\text { My interaction with other } \\
\text { event attendees (spectators) } \\
\text { was friendly }\end{array}$ & 2.59 & .842 & & -.645 \\
\hline IA3 & $\begin{array}{l}\text { My interaction with other } \\
\text { event attendees (spectators) } \\
\text { was co-operative }\end{array}$ & 2.98 & & -.432 & -.548 \\
\hline IA4 & $\begin{array}{l}\text { My interaction with other } \\
\text { event attendees (spectators) } \\
\text { was frequent }\end{array}$ & & .945 & -.312 & -.544 \\
\hline IA5 & $\begin{array}{l}\text { My interaction with other } \\
\text { event attendees (spectators) } \\
\text { was close }\end{array}$ & 2.57 & .911 & -.254 & -.234 \\
\hline IA6 & $\begin{array}{l}\text { My interaction with other } \\
\text { event attendees (spectators) } \\
\text { was intense }\end{array}$ & 3.12 & .834 & -.311 & -.301 \\
\hline \multicolumn{6}{|c|}{ Interaction with local community providers (Yang, 2016) } \\
\hline IP1 & $\begin{array}{l}\text { My interaction with local } \\
\text { community providers was } \\
\text { harmonious }\end{array}$ & 3.45 & .922 & .287 & -.632 \\
\hline IP2 & $\begin{array}{l}\text { My interaction with local } \\
\text { community providers was } \\
\text { friendly }\end{array}$ & 2.54 & .902 & .276 & -.543 \\
\hline IP3 & $\begin{array}{l}\text { My interaction with local } \\
\text { community providers was co- } \\
\text { operative }\end{array}$ & 3.90 & .877 & .561 & -.391 \\
\hline IP4 & $\begin{array}{l}\text { My interaction with local } \\
\text { community providers was } \\
\text { frequent }\end{array}$ & 4.27 & .837 & -.477 & -.422 \\
\hline IP5 & $\begin{array}{l}\text { My interaction with local } \\
\text { community providers was } \\
\text { close }\end{array}$ & 4.56 & .920 & -.023 & -.223 \\
\hline IP6 & $\begin{array}{l}\text { My interaction with local } \\
\text { community providers was } \\
\text { intense }\end{array}$ & 3.67 & .881 & -.219 & -.431 \\
\hline
\end{tabular}




\begin{tabular}{|c|c|c|c|c|c|}
\hline \multicolumn{6}{|c|}{ Interaction with local community participants (Yang, 2016) } \\
\hline IC1 & $\begin{array}{l}\text { My interaction with local } \\
\text { community participants was } \\
\text { harmonious }\end{array}$ & 2.45 & .864 & .267 & -.511 \\
\hline IC2 & $\begin{array}{l}\text { My interaction with local } \\
\text { community participants was } \\
\text { friendly }\end{array}$ & 2.67 & .951 & .266 & -.487 \\
\hline IC3 & $\begin{array}{l}\text { My interaction with local } \\
\text { community participants was } \\
\text { co-operative }\end{array}$ & 3.76 & .823 & -.418 & -.467 \\
\hline IC4 & $\begin{array}{l}\text { My interaction with local } \\
\text { community participants was } \\
\text { frequent }\end{array}$ & 4.03 & .776 & -.478 & -.389 \\
\hline IC5 & $\begin{array}{l}\text { My interaction with local } \\
\text { community participants was } \\
\text { close }\end{array}$ & 4.76 & .845 & & -.201 \\
\hline IC6 & $\begin{array}{l}\text { My interaction with local } \\
\text { community participants was } \\
\text { intense }\end{array}$ & 4.65 & & & -.422 \\
\hline \multicolumn{6}{|c|}{ Overall interaction (Yang, 2016) } \\
\hline OI1 & $\begin{array}{l}\text { My interaction with other } \\
\text { people during the Chios ERW } \\
\text { made me feel a friendly event } \\
\text { atmosphere } \\
\end{array}$ & & & -.319 & -.455 \\
\hline $\mathbf{O I 2}$ & $\begin{array}{l}\text { My interaction with other } \\
\text { people during the Chios ERW } \\
\text { made me feel a hospitable } \\
\text { event atmosphere }\end{array}$ & 3.28 & .843 & -.514 & -.478 \\
\hline $\mathbf{O I 3}$ & $\begin{array}{l}\text { My interaction with other } \\
\text { people during the Chios ERW } \\
\text { made me feel a pleasant event } \\
\text { atmosphere }\end{array}$ & 2.56 & .912 & -.411 & -.356 \\
\hline OI4 & $\begin{array}{l}\text { My interaction with other } \\
\text { people during the Chios ERW } \\
\text { made me feel an exciting } \\
\text { event atmosphere }\end{array}$ & 2.15 & .778 & -.345 & -.512 \\
\hline \multicolumn{6}{|c|}{ Event Image Co-creation (Lee \& Lee, 2019; Yi \& Gong, 2013) } \\
\hline EIC1 & $\begin{array}{l}\text { I felt united with the people } \\
\text { around me as I was } \\
\text { experiencing the Chios ERW }\end{array}$ & 3.23 & .777 & -.321 & -.546 \\
\hline EIC2 & $\begin{array}{l}\text { ERW gave me a sense of the } \\
\text { Chios cultural traditions }\end{array}$ & 1.24 & .812 & -.234 & -.563 \\
\hline EIC3 & $\begin{array}{l}\text { ERW made me feel the Chios } \\
\text { authenticity }\end{array}$ & 1.27 & .987 & -.433 & -.478 \\
\hline EIC4 & $\begin{array}{l}\text { The Chios ERW experience } \\
\text { seemed sacred }\end{array}$ & 3.56 & .932 & -.441 & -.456 \\
\hline EIC5 & $\begin{array}{l}\text { The Chios ERW experience } \\
\text { seemed reverent }\end{array}$ & 3.22 & .845 & -.337 & -.512 \\
\hline
\end{tabular}




\begin{tabular}{|l|l|c|c|c|c|}
\hline EIC6 & $\begin{array}{l}\text { I will recommend the Chios } \\
\text { ERW to other people }\end{array}$ & 1.57 & .867 & -.238 & -.523 \\
\hline EIC7 & $\begin{array}{l}\text { I will share positive things } \\
\text { about the Chios ERW to other } \\
\text { people }\end{array}$ & 2.56 & .923 & -.456 & -.367 \\
\hline EIC8 & $\begin{array}{l}\text { I will encourage friends and } \\
\text { relatives to attend the Chios } \\
\text { ERW }\end{array}$ & 2.67 & .858 & -.234 & -.462 \\
\hline EIC9 & $\begin{array}{l}\text { I will definitely revisit the } \\
\text { Chios ERW }\end{array}$ & 3.56 & .865 & -.437 & -.545 \\
\hline
\end{tabular}

*Easter Rocket War (ERW) 
Table 3

Validity and Reliability Analysis

\begin{tabular}{|c|c|c|c|c|}
\hline \multirow{2}{*}{\multicolumn{2}{|c|}{ Place Attachment }} & \multirow{3}{*}{$\frac{\mathrm{A}}{.851}$} & \multirow{3}{*}{$\begin{array}{r}\text { AVE } \\
.674\end{array}$} & \multirow{3}{*}{$\begin{array}{r}\text { CR } \\
.910\end{array}$} \\
\hline & & & & \\
\hline PA 1 & .847 & & & \\
\hline PA 2 & .935 & & & \\
\hline PA 3 & .876 & & & \\
\hline PA 4 & .781 & & & \\
\hline PA 5 & .632 & & & \\
\hline \multicolumn{2}{|c|}{ Event Brand } & .802 & & .882 \\
\hline EB 1 & .844 & & & \\
\hline EB 2 & .963 & & & \\
\hline EB 3 & .812 & & & \\
\hline EB 4 & .522 & & & \\
\hline \multicolumn{5}{|l|}{ EB 5} \\
\hline \multicolumn{5}{|l|}{ EB 6} \\
\hline \multicolumn{2}{|c|}{ User-generated Content } & .823 & .630 & .867 \\
\hline \multicolumn{5}{|c|}{ UGC 1} \\
\hline \multicolumn{5}{|c|}{ UGC 2} \\
\hline \multicolumn{5}{|c|}{ UGC 3} \\
\hline \multicolumn{5}{|c|}{ UGC 4} \\
\hline \multirow{2}{*}{\multicolumn{2}{|c|}{ Interaction with Event Attendees }} & & & \\
\hline & & .757 & .559 & .861 \\
\hline \multicolumn{2}{|l|}{ IA 1} & & & \\
\hline IA 2 & .707 & & & \\
\hline \multicolumn{5}{|l|}{ IA 3} \\
\hline IA 4 & .897 & & & \\
\hline IA 5 & .765 & & & \\
\hline IA 6 & .562 & & & \\
\hline \multicolumn{2}{|c|}{$\begin{array}{l}\text { Interaction with Local Community } \\
\text { Providers }\end{array}$} & .723 & .530 & .818 \\
\hline IP 1 & .789 & & & \\
\hline IP 2 & .726 & & & \\
\hline IP 3 & .712 & & & \\
\hline IP 4 & .682 & & & \\
\hline \multicolumn{5}{|l|}{ IP 5} \\
\hline IP 6 & & & & \\
\hline
\end{tabular}




\begin{tabular}{|c|c|c|c|c|}
\hline \multicolumn{2}{|c|}{$\begin{array}{l}\text { Interaction with Local Community } \\
\text { Participants }\end{array}$} & \multirow[t]{2}{*}{.746} & \multirow[t]{2}{*}{.511} & \multirow[t]{2}{*}{.807} \\
\hline IC 1 & .778 & & & \\
\hline IC 2 & .712 & & & \\
\hline IC 3 & .703 & & & \\
\hline IC 4 & .662 & & & \\
\hline \multicolumn{5}{|l|}{ IC 5} \\
\hline \multicolumn{5}{|l|}{ IC 6} \\
\hline \multicolumn{5}{|c|}{ Overall Interaction } \\
\hline OI 1 & .847 & .749 & .6 & .857 \\
\hline OI 2 & .532 & & & \\
\hline OI 3 & .763 & & & \\
\hline OI 4 & .923 & & & \\
\hline \multicolumn{2}{|c|}{ Event Image Co-creation } & & .658 & .938 \\
\hline EIC 1 & .612 & & & \\
\hline EIC 2 & .927 & & & \\
\hline EIC 3 & .934 & & & \\
\hline \multicolumn{5}{|l|}{ EIC 4} \\
\hline \multicolumn{5}{|l|}{ EIC 5} \\
\hline \multicolumn{5}{|l|}{ EIC 6} \\
\hline \multicolumn{5}{|l|}{ EIC 7} \\
\hline EIC 8 & .823 & & & \\
\hline EIC 9 & .797 & & & \\
\hline
\end{tabular}

Absolute loading values suppressed to .4 


\section{Table 4}

Content Analysis Findings

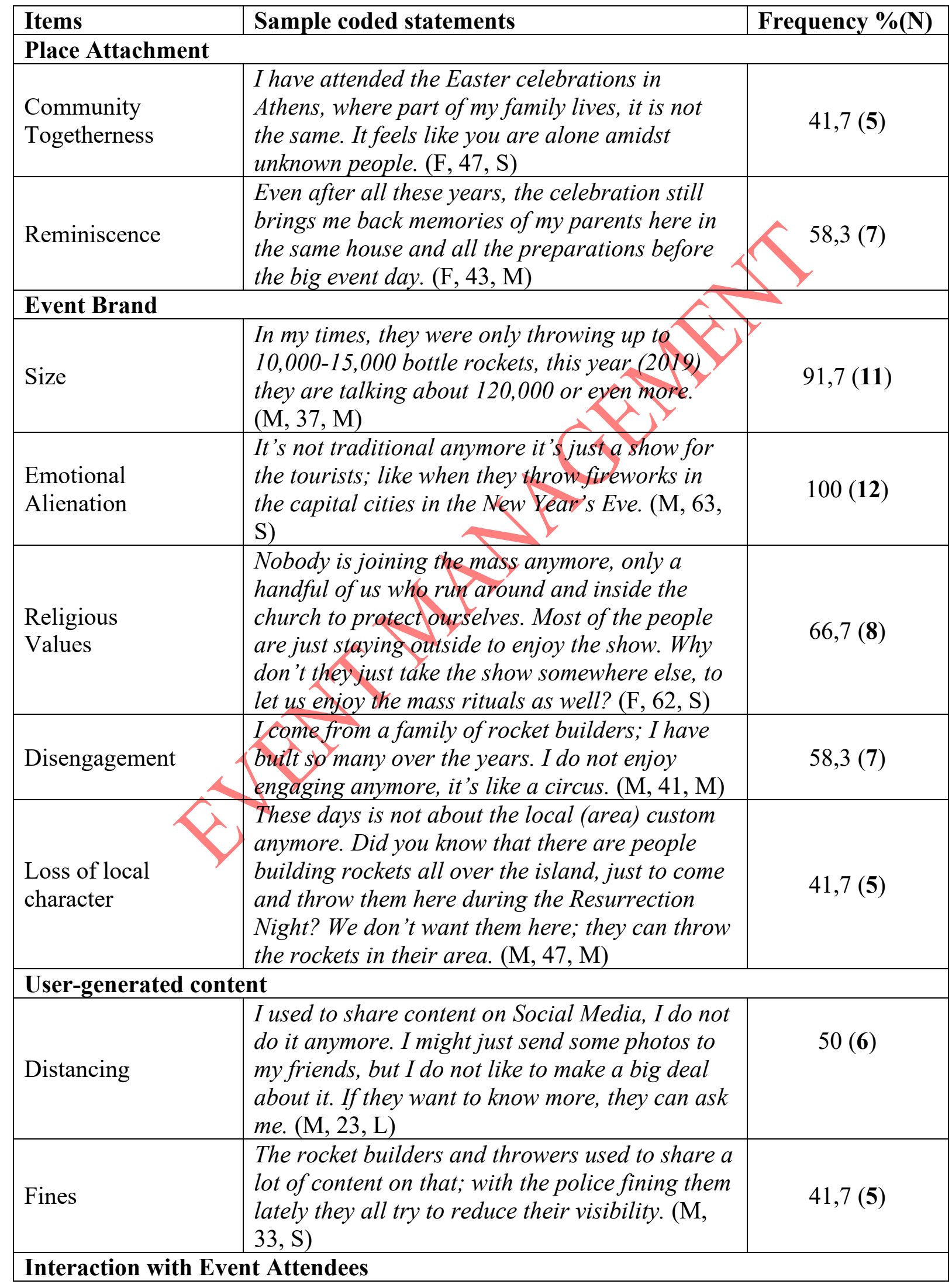




\begin{tabular}{|c|c|c|}
\hline Intensity & $\begin{array}{l}\text { I do not really interact with them. They only } \\
\text { come for one hour, they see the Rocket War and } \\
\text { then they go away. }(\mathrm{F}, 62, \mathrm{~S})\end{array}$ & $50(6)$ \\
\hline Quality & $\begin{array}{l}\text { If you think about it, it's not their fault. It's the } \\
\text { others [tourist agents and stakeholders] who } \\
\text { convince them to come to make money from } \\
\text { tourism. }(\mathrm{M}, 47, \mathrm{M})\end{array}$ & $33,3(4)$ \\
\hline \multicolumn{3}{|c|}{ Interaction with local community providers } \\
\hline Conflicts & $\begin{array}{l}\text { You can't image the problems this situation has } \\
\text { created. We stopped talking with people in the } \\
\text { neighbourhood just because their house } \\
\text { (property) is not affected as much as ours. (F, } \\
62, \mathrm{~S})\end{array}$ & $75,5(9)$ \\
\hline Marginalisation & $\begin{array}{l}\text { They [local community living around the affected } \\
\text { area] think that we are just exaggerating, and } \\
\text { we wouldn't care if the custom disappeared. (M, } \\
41, \mathrm{M})\end{array}$ & $83,3(\mathbf{1 0})$ \\
\hline Frustration & $\begin{array}{l}\text { I am tired of having to clean my house and } \\
\text { property the whole Easter day after the eyent, } \\
\text { while everybody else is relaxing and celebrating } \\
\text { with their families. }(\mathrm{F}, 47, \mathrm{~S})\end{array}$ & $83,3(\mathbf{1 0})$ \\
\hline \multicolumn{3}{|c|}{ Overall interaction } \\
\hline Avoidance & $\begin{array}{l}\text { Over the last years, I am not even staying at my } \\
\text { home during the time of the event. I have been } \\
\text { going in the village of my relatives and spend the } \\
\text { holiday there in a smaller cycle and more } \\
\text { reverent atmosphere. I only return back after the } \\
\text { whole craziness is finished. }(\mathrm{M}, 53, \mathrm{~S})\end{array}$ & $33,3(4)$ \\
\hline \multicolumn{3}{|c|}{ Event Image Co-creation $y$} \\
\hline Pride & $\begin{array}{l}\text { Ido take a lot of pride on talking about the } \\
\text { tradition and the origins of the event with my } \\
\text { friends. I do not mind them coming there. I just } \\
\text { feel uncomfortable with the big numbers of all } \\
\text { these unknown people coming here and walking } \\
\text { around my home. (M, 37, M) }\end{array}$ & $41,7(5)$ \\
\hline Commodification & $\begin{array}{l}\text { It is unique and authentic only for the tourists; } \\
\text { not for us anymore. }(\mathrm{M}, 53, \mathrm{~S})\end{array}$ & $50(6)$ \\
\hline Experience & $\begin{array}{l}\text { The tourists do not care about us; they are not } \\
\text { here to see us, they are just here for the one hour } \\
\text { of the Rocket War. Just organise the event } \\
\text { somewhere else and take the tourists there, they } \\
\text { won't even realise the difference. }(\mathrm{F}, 62, \mathrm{~S})\end{array}$ & $50(6)$ \\
\hline
\end{tabular}




\section{Figure 1}

Hypothetical Model for Event Image Co-Creation

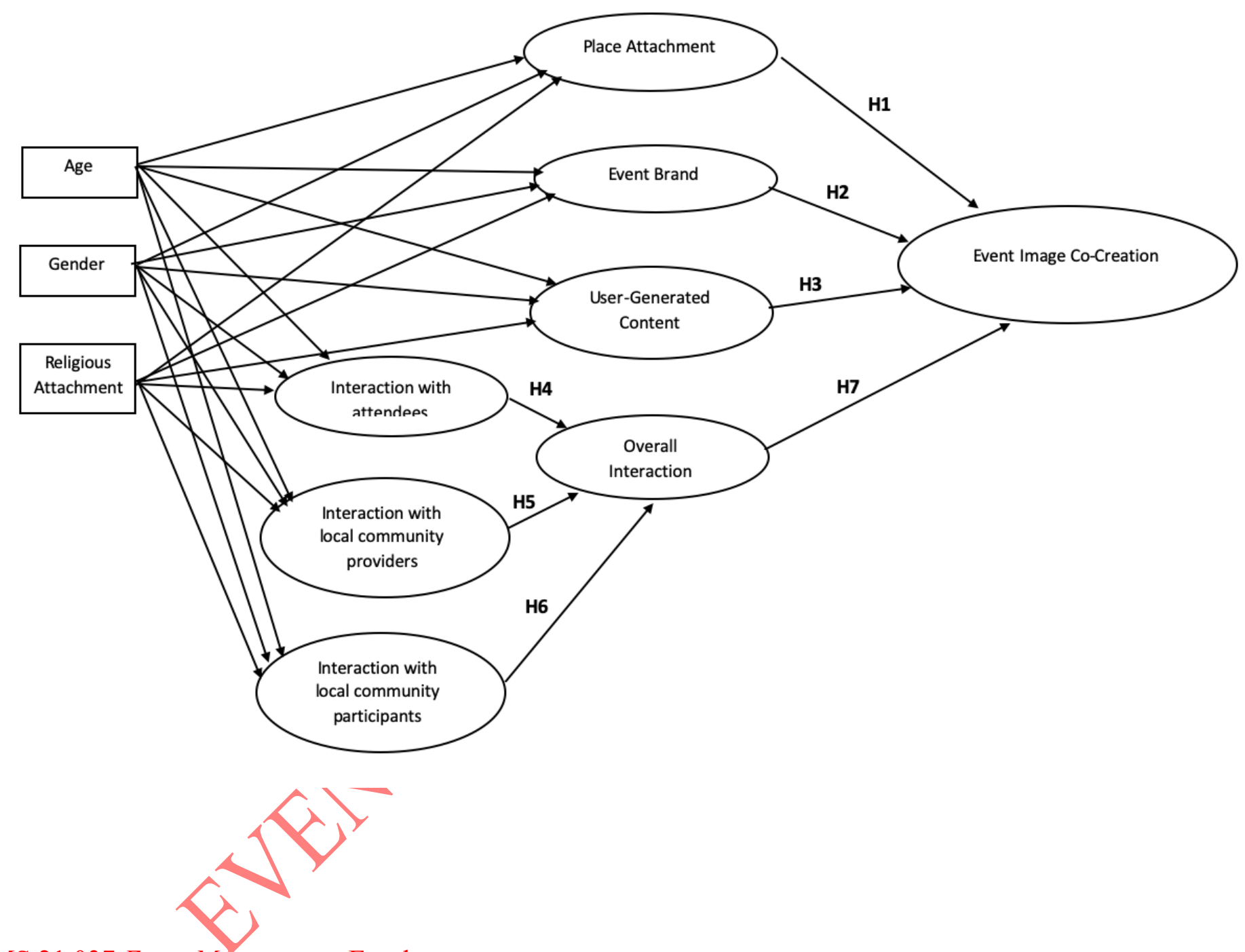

MS 21037 Event Management E-pub 
Figure 2

Event Image Co-Creation Model

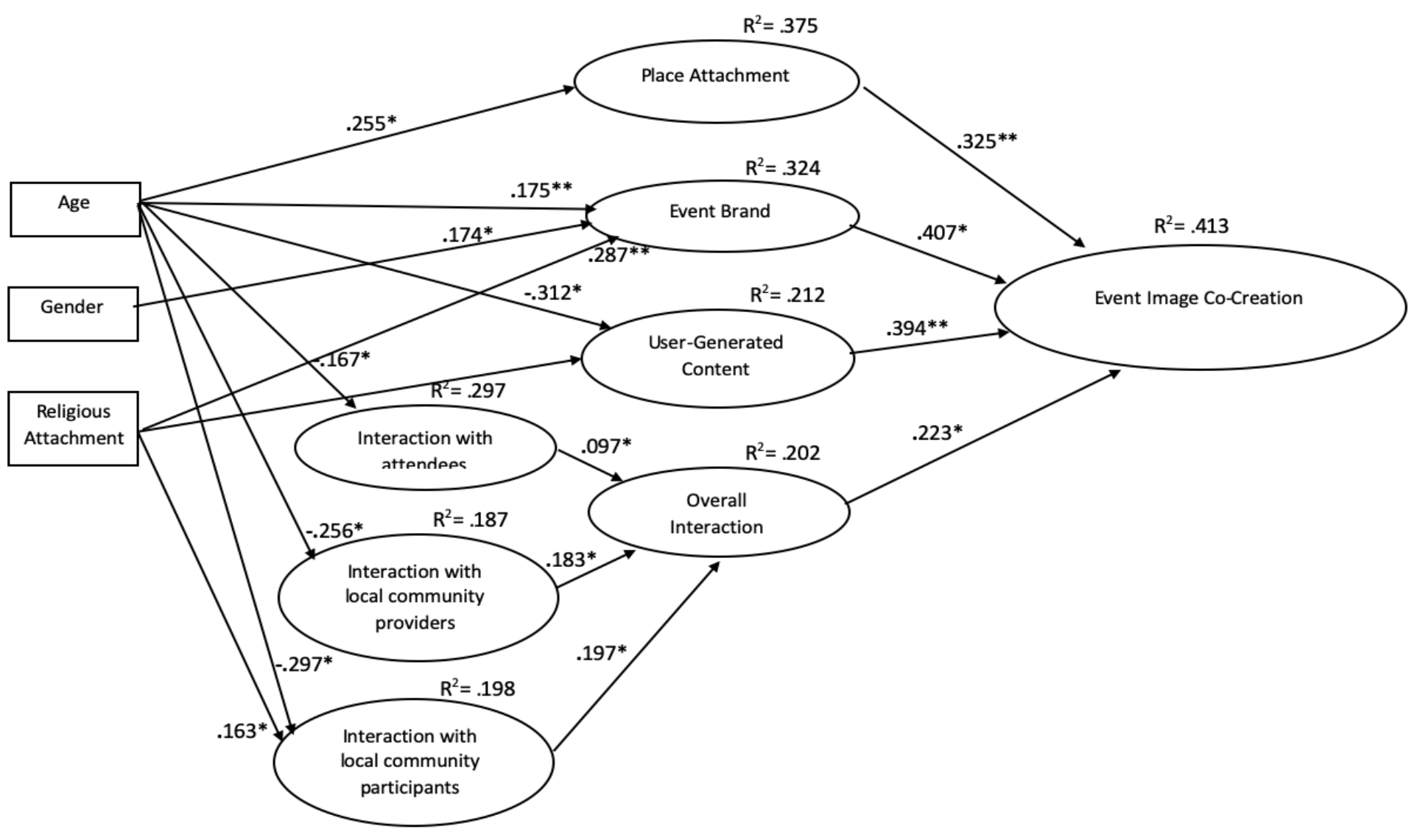

* Coefficient's significance at .05 level

** Coefficient's significance at .01 level 